\title{
Coniferous Cones as a Forestry Waste Biomass-A Source of Antioxidants ${ }^{+}$
}

\author{
Tamás Hofmann *, Levente Albert, Balázs Bocz, Dániel Bocz and Eszter Visi-Rajczi
}

Citation: Hofmann, T.; Albert, L. Bocz, B.; Bocz, D.; Visi-Rajczi, E. Coniferous Cones as a Forestry Waste Biomass-A Source of Antioxidants. Environ. Sci. Proc. 2021, 3, 82. https://doi.org/ 10.3390/IECF2020-07766

Academic Editors: Angela Lo Monaco, Cate Macinnis-Ng and Om P. Rajora

Published: 10 November 2020

Publisher's Note: MDPI stays neutral with regard to jurisdictional claims in published maps and institutional affiliations.

Copyright: $\subset 2020$ by the authors. Licensee MDPI, Basel, Switzerland. This article is an open access article distributed under the terms and conditions of the Creative Commons Attribution (CC BY) license (http://creativecommons.org/licenses/by/4.0/).
Institute of Chemistry, University of Sopron, H-9400 Sopron, Hungary; albert.levente@uni-sopron.hu (L.A.); bocz.balazs338@gmail.com (B.B.); boci543@gmail.com (D.B.); visine.rajczi.eszter@uni-sopron.hu (E.V.-R.)

* Correspondence: hofmann.tamas@uni-sopron.hu

† Presented at the 1st International Electronic Conference on Forests - Forests for a Better Future: Sustainability, Innovation, Interdisciplinarity, 15-30 November 2020; Available online: https://iecf2020.sciforum.net.

\begin{abstract}
The cones of conifers are a waste biomass, potentially be utilized for a variety of purposes, including the extraction of bioactive materials, particularly antioxidant polyphenols. In the present work we conducted a comparative analysis of the antioxidant content of selected taxa that are either common in Hungary or that have not yet been investigated in any great detail (Cedrus atlantica, Larix decidua, Picea abies, Pinus mugo, Pinus nigra, Pinus sylvestris, Pinus wallichiana, Tsuga Canadensis, Tsuga heterophylla, Pseudotsuga menziesii, Chamaecyparis lawsoniana, Taxodium distichum, Thuja occidentalis, Metasequoia glyptostroboides, Thuja orientalis, Cryptomeria Japonica, Cunninghamia lanceolata). A comparison of different maturation stages (green, mature, and opened cones) was carried out for the assigned taxa. Folin-Ciocâlteu total phenol content, ferric reducing antioxidant power (FRAP) and 2,2-diphenyl-1-picrylhydrazyl (DPPH) assays were used to assess the antioxidant contents. Total antioxidant power was determined by a scoring system that combined the three assay results. For each taxon the overall best results were found for green cones, followed by mature, and opened cones. Taxa with the highest scores were Tsuga Canadensis, Metasequoia glyptostroboides, Chamaecyparis lawsoniana, Cryptomeria Japonica, Thuja orientalis and Picea abies. High-performance liquid chromatographic/tandem mass spectrometric profiling of the polyphenols was completed for selected samples. Results provide a basis for future bioactivity testing of these samples. The research was supported by the ÚNKP-20-5-12 New National Excellence Program of the Ministry for Innovation and Technology from the source of the National Research, Development and Innovation Fund and by the János Bolyai Research Scholarship of the Hungarian Academy of Sciences.
\end{abstract}

Supplementary Materials: The following are available online at https://www.mdpi.com/2673$4931 / 3 / 1 / 82 / s 1$. 